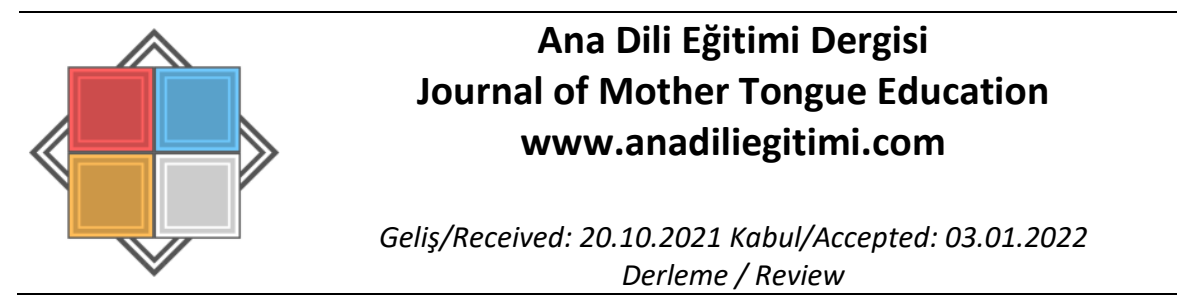

\title{
Sosyoekonomik Risk Faktörlerinin Ebeveyn-Çocuk Etkileşimindeki Rolü: Paylaşımlı Kitap Okuma, Çocuğa Yöneltilen Dil, Sözcük Dağarcığı Farkı
}

\author{
Figen TURAN* \\ Raziye YÜKSEL DOĞAN**
}

\begin{abstract}
Öz
Dil gelişimi, doğumdan itibaren hızlı bir şekilde gelişmeye başlayarak, yaşam boyu devam eden bir süreçtir. Ebeveynin çocuğuna yönelttiği dil, çocukların dil gelişimini şekillendiren en önemli çevresel faktörlerden biridir. Ebeveynlerin sosyoekonomik düzeyine bağı olarak çocuklarına yönelttiği dilin niceliği ve niteliği arasında farklılıklar olduğu görülmekte olup bu farkılıkların, 21. yüzyılın en önemli risk faktörlerinden biri olduğu düşünülmektedir. Bu derlemede, erken dönemde işitilen sözcük sayısı başta olmak üzere ebeveynin çocuğa yönelttiği dil ve paylaşımlı kitap okuma gibi ebeveyn-çocuk etkileşiminde sosyoekonomik durumdan kaynaklanan farklılıkların ele alınması amaçlanmıştır. Bu kapsamda çalışmada, erken dönemde gelir düzeyi düşüklüğü sonucu oluşabilecek risk faktörleri üzerinde durulmuş ve risk altındaki çocukların gelişimsel potansiyelini en uygun seviyeye ulaştırmak amacıyla ebeveynleri güçlendirmeye yönelik ulusal ve uluslararası düzeyde erken çocukluk dönemi organizasyonları ele alınmıştır.
\end{abstract}

Anahtar Kelimeler: dil gelişimi, sosyoekonomik durum, çocuğa yöneltilen dil, 30 milyon sözcük farkı, paylaşımlı kitap okuma

\section{The Role of Socioeconomic Risk Factors in Parent-Child Interaction: Shared Book Reading, Child-Directed Speech, Million Word Gap}

\begin{abstract}
Language development is a lifelong process that begins at birth. Child-directed speech is among the most critical environmental factors that shape children's language development. Depending on parental socioeconomic status, there are differences in the quality and quantity of childdirected speech, which can be counted among the important risk factors in the $21^{\text {st }}$ century. The present review aimed to address socioeconomic differences in parent-child interactions, such as child-directed speech and shared book reading, especially the number of words heard in the early period. In this context, the study focused on likely risk factors due to income inequality in early childhood and discussed early childhood organizations at national and international levels to empower parents to optimize the development of their at-risk children.

Keywords: language development, socioeconomic status, child-directed speech, 30-million-word gap, shared book reading
\end{abstract}

\section{Giriş}

Dil gelişimi, doğumdan itibaren hızlı bir şekilde başlayarak, yaşam boyu devam eden bir süreçtir. Çocuklar, çevresinde konuşulanları anlayabilecek biyolojik bir yapı ile dünyaya gelmektedir. Başlangıçta, sesleri, sözcükleri işitmeye ve anlamlandırmaya yönelik olan bu süreç; ilerleyen yıllarda iletişim kurma amaçlı dilin aktif bir biçimde kullanılmasını sağlamaya doğru evrilir (Cirhinlioğlu, 2015).

\footnotetext{
* Prof. Dr., Hacettepe Üniversitesi, Sağlık Bilimleri Fakültesi, Çocuk Gelişimi Bölümü, Ankara, ffigenturan@gmail.com, ORCID: orcid.org/ 0000-0002-9785-105X

** Arş. Gör., Hacettepe Üniversitesi, Sağlık Bilimleri Fakültesi, Çocuk Gelişimi Bölümü, Ankara, raziye.yuksel@hacettepe.edu.tr, ORCID: orcid.org/0000-0002-9620-9081
} 
Bu noktada, bir çocuğun dili hangi aşamalardan geçerek edindiğine yönelik çok sayıda araştırmanın farklı bulguları ile karşılaşılsa da dilin hangi etkenler doğrultusunda ne şekilde kazanıldığı sorusu dil gelişimi alanına yönelik kuramlar perspektifinde ele alınabilmektedir (Turan ve Topcu, 2016).

Dil gelişimi sürecini açıklamaya yönelik kuramlar incelendiğinde; 1970'li yılların ortalarından önce çocuklardaki dil gelişimi ile ilgili yaklaşımlarda temel olarak kalıtsalcılık ve çevreselcilik (nature vs nurture) kutuplaşması dikkati çekmektedir (McLean 1990'dan aktaran Karacan, 2000). Bu çerçevede, dil gelişimine yönelik kuramsal yaklaşımlar genel olarak gözden geçirilmiştir. Davranışçı kuramın öncülerinden olan Skinner ve onu destekleyenler, dilin çevreden gelen uyaranlar ve deneyimler yoluyla kazanıldığı görüşünü savunarak (McLean 1990'dan aktaran Karacan, 2000); dili öğrenmede pekiştireçlerin önemli olduğunu vurgulamaktadır (Senemoğlu, 1989). Gelişimsel bilişsel yaklaşımın öncülerinden olan Jean Piaget'e (1954) göre biliş, dil gelişimi için gerekli görülen önemli bir faktördür ve bilişsel gelişimde meydana gelen değişimler dilin gelişimine katkı sağlamaktadır (Maviş, 2005). Dilbilim modelinin savunucusu olan Chomsky ve onu destekleyenler, dilin öğrenildiği çevrenin özelliklerinden bağımsız bir biçimde biyolojik ve nörolojik gelişime bağlı olarak doğuştan getirilen bir özellik olduğunu belirterek evrensel bir dil gelişimi sürecini vurgulamaktadır (Maviş, 2005; Öztürk Dağabakan ve Dağabakan, 2007). Etkileşim temelli yaklaşımlar ve sosyal etkileşime odaklanan gözleme dayalı çalışmaların artmasıyla birlikte günümüzde dil edinimi; doğumdan hemen sonra çocukla bakım vereni (en yakını) arasındaki iletişimden temel alan ve yetişkinliğe kadar karmaşık bir biçimde devam eden çok boyutlu ve sürekli bir süreç olarak değerlendirilebilmektedir (Zollinger 1994'den aktaran Öztürk Dağabakan ve Dağabakan, 2007). Bu noktada, bütün dünyadaki çocukların, dil aşamalarını yaklaşık olarak benzer bir sırada geçirdiğinin altını çizmek önemli görülmektedir (Santrock, 2014).

Gelişimsel olarak çocuklar; bir yaşında konuşmaya, iki yaşında basit cümleler oluşturmaya, üç yaşında basit hikayeler anlatmaya, dört yaşında karmaşık yollarla düşüncelerini ifade etmeye, okul yılları boyunca daha yetenekli iletişimciler haline gelmeye başlamaktadırlar (Finnegan, Telfer, Warren, Lawton ve Nutbrown, 2015). Dil edinimi temel olarak her çocukta benzer sırayı takip ediyor olsa da bu gelişimin hızı, bireysel özelliklere ve çocuğun sosyal çevresi ile olan etkileşimine bağlı olarak farklılık göstermektedir (Anlar, Serdaroğlu ve Yakut, 2008). Bazı bebekler, henüz ilk sözcüklerini bir yaşına girmeden önce üretirken, bazıları çok geç konuşmaya başlamaktadır. Bazı bebekler, geç konuşmaya başlasa da kısa zaman içerisinde yaşına uygun bir sözcük dağarcığına sahip olurken bazıları için bu süre çok daha yavaş ilerlemektedir (Fenson vd. 2006'dan aktaran Fernald, Marchman ve Weisleder, 2013). Bu noktada ebeveynin çocuğu ile olan iletişimi; erken dönemde dil ve beyin gelişimi açısından oldukça önemli bir konumdadır. Bu durum, dil edinimi süreci açısından "kritik dönem" olarak nitelendirilmektedir (Anlar vd., 2008). Kritik dönemde, çocukların ebeveynleriyle olan etkileşime yönelik erken yaşam deneyimleri; beyin gelişimini ve bilişsel kapasitenin altında yatan temel işlevleri şekillendirmektedir (Romeo vd., 2018). Beyin gelişimi açısından ebeveyn konuşması; bazı sinirsel bağların dayanıklııı̆ını ve kalıcılı̆ını belirlerken; diğerlerini budayarak ortadan kaldırmada önemli bir katalizör görevini üstlenmektedir. Başka bir deyişle, bireylerin sahip olduğu genetik potansiyele ulaşabilmelerinde çocukken ebeveynler tarafından sunulan dil ortamının niteliği önemli bir konumdadır ve erken dönemde dil gelişiminde farklııklar görülebilmektedir (Suskind, 2018).

Erken dil edinimindeki farklılığı açıklamada önemli bir faktör; çocukların işittiği dilsel girdinin miktarı ve kalitesidir (Hart ve Risley, 1995; Hoff, 2003b; Huttenlocher, Haight, Bryk, Seltzer ve Lyons, 1991). Ebeveynin çocuğu ile konuştuğu sözcük sayısı ve konuşma şekli (cümle karmaşıklığı, sözcük çeşitliği) ilerleyen yıllarda çocukların, dil ve okuryazarlık (Hirsh-Pasek vd., 2015; Rodriguez ve TamisLeMonda, 2011; Rowe, 2008), uzamsal akıl yürütme (Sarsour vd., 2011), matematik (Levine, Suriyakham, Rowe, Huttenlocher ve Gunderson, 2010) ve sosyal beceriler (Connell ve Prinz, 2002) dahil olmak üzere sözel ve sözel olmayan becerilerinin temelini oluşturmaktadır. Erken dönem dil edinimine yönelik yapılan çalışmalarda; çocukların dile maruz kalmalarının, ebeveynlerin sosyoekonomik durumlarına bağlı olarak farklıık gösterdiği bulgusu oldukça dikkat çekicidir (Fernald vd., 2013; Hart ve Risley, 1995; Hoff, 2006; Hoff, Laursen ve Tardif, 2002). Bu bağlamda bu derlemede, erken dönemde işitilen sözcük sayısı başta olmak üzere ebeveynin çocuğa yönelttiği dil ve 
paylaşımlı kitap okuma gibi ebeveyn-çocuk etkileşiminde sosyoekonomik düzeyden kaynaklanan farklıııkların gelişimsel bir bakış açısıyla ele alınması amaçlanmaktadır. Bu kapsamda makalede, sosyoekonomik düzeyden kaynaklanan risk durumuna bağı farklılıkların çocukların gelişimi üzerindeki etkilerine genel olarak değinilecek ve çocukların gelişimsel potansiyelini optimum seviyeye ulaştırmak amacıyla ebeveynleri güçlendirmeye yönelik ulusal ve uluslararası düzeyde erken çocukluk dönemi organizasyonları gözden geçirilecektir.

\section{Sosyoekonomik Farklılıklar ve İşitilen Sözcük Sayısı "30 Milyon Sözcük Farkı”}

Sosyoekonomik düzeyi düşük ve yüksek olan ailelerin çocuklarının sözcük dağarcığı arasındaki fark, 21. yüzyııın en büyük risk faktörlerinden biri olarak karşımıza çıkmaktadır. Çocukların işittiği sözcük sayısının sosyoekonomik düzeye göre farklılaştığı fikri; Hart ve Risley'in $(1995,1999,2003)$ çeşitli sosyoekonomik geçmişe sahip 42 ebeveyn ve bu ebeveynlerin çocuklarını gözlemlediği araştırmalarının bulguları sonucunda ortaya çıkmıştır. Betty Hart ve Todd Risley, 1960'lı yıllarda Amerika Birleşik Devletleri'nde "yoksulluk döngüsünü" kırmak üzere Kansas Üniversitesi'ndeki meslektaşlarıyla birlikte sosyoekonomik açıdan dezavantajı olan çocukların akademik becerilerini geliştirmeye yönelik dil temelli bir müdahale programı oluşturmuştur. Tüm çocukların istekli bir biçimde katılım gösterdiği belirtilen müdahale programının kısa vadede; çocukların yeni sözcük dağarcığı ve kümülatif sözcük dağarcı̆̆ında hızlı bir artış yaşamasına katkı sağladığı ancak uzun vadede söz konusu etkinin kalıcı olmadığı rapor edilmiştir. illgili müdahalenin uzun vadedeki başarısızlığı; genetik veya değiştirilmesi güç etmenlere atfedilmek yerine, problemin çözümüne yönelik çeşitli girişimlerde bulunulmuştur. Bu çerçevede mevcut çalışmanın odağı, erken dönemde dile maruz kalınan "ev ortamı" olarak değiştirilmiştir. Bu doğrultuda, "yüksek" sosyoekonomik düzeye sahip 13 aile, "orta" sosyoekonomik düzeye sahip 10 aile, "düşük" sosyoekonomik düzeye sahip 13 aile ve devlet desteği alarak geçinen 6 aile olmak üzere toplamda 42 aile ve bu ailelerin 7-9 ay arasındaki bebekleri araştırmaya dahil edilmiştir. Çalışmada, ev ortamında yapılan gözlemler sırasında "her şeyin kayıt altına alınması" planlanmış olup çalışma üç yıl sürmüştür. Üç yıl süre boyunca ayda bir kere bir saatlik gözlem yapmak üzere ev ziyareti gerçekleştiren araştırmacılar, ev ziyareti sırasında her şeyi ses kayıt cihazına kaydederek ebeveynlerin konuştukları sözcük sayısını ve çocuklarıyla olan etkileşim biçimlerini gözlemiştir. Çalışmanın bulguları incelendiğinde;

- Ailelerin ilk sekiz ay boyunca çocukları ile yaptığı konuşma miktarı, çocukları üç yaşına geldiğinde yapacağı konuşma miktarını yordamaktadır.

- Çocukların üç yaşına geldiğinde kullandığı sözcükler, \%86 ile \%98 oranında ebeveynlerinin kullandığı sözcüklerle örtüşmektedir. Çocukların kullandığı sözcük sayısı, konuşma süresi ve konuşma kalıpları ebeveynlerinin konuşma biçimine benzerlik göstermektedir.

- Farklı sosyoekonomik düzeylerden gelen ebeveynlerin kullandığı onay verici veya yasaklayıcı ifadelerin sıklığı açısından farklııklar bulunmaktadır. Yüksek sosyoekonomik düzeye sahip ailelerin ( $n=13)$ saatte yaklaşık 32 olumlu, 5 yasaklayıcı ifade; orta-düşük sosyoekonomik düzeye sahip ailelerin $(n=26)$ saatte yaklaşık 12 olumlu, 7 yasaklayıcı ifade; devlet yardımı alan ailelerin $(n=6)$ saatte yaklaşık 5 olumlu, 11 yasaklayıcı ifade kullandığı tespit edilmiştir. Bu doğrultuda, yüksek sosyoekonomik düzeye sahip ailelerin, düşük gelirli ailelere göre çok daha fazla onay ifadeleri kullandığı belirtilmiştir.

- Farklı sosyoekonomik düzeylerden gelen ebeveynlerin konuştukları sözcük sayıları arasında da farklılıklar göze çarpmaktadır. Bir saat içerisinde devlet desteği alan ailelerin çocukları $(n=6)$ yaklaşık 600 sözcük işitirken, düşük-orta sosyoekonomik düzeyde olan ailelerin çocukları $(n=26)$ yaklaşık 1200 sözcük, yüksek sosyoekonomik düzeye sahip ailelerin çocukları $(n=13)$ ortalama 2000 sözcük işitmektedir (Bkz. Şekil 1). 


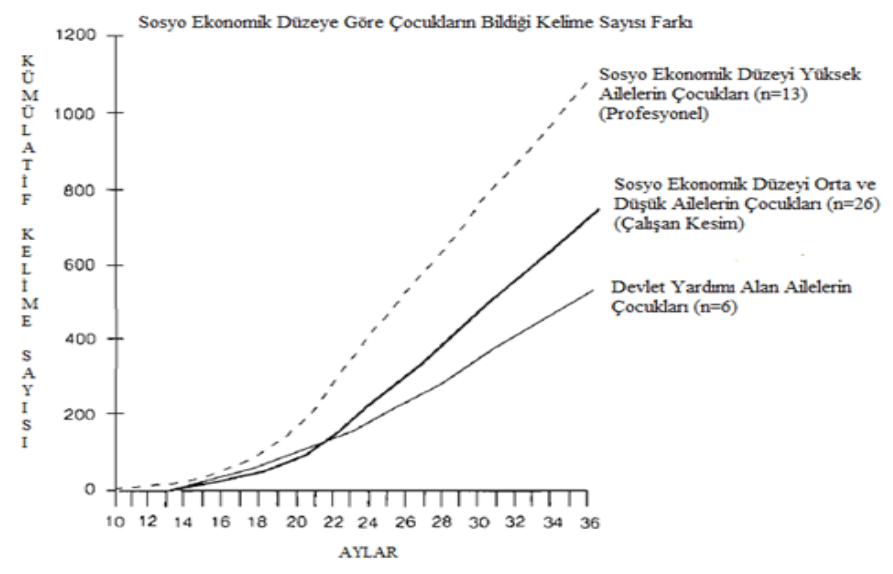

Şekil 1. Sosyo Ekonomik Düzeye Göre Çocukların İşittiği Sözcük Sayısı Farkı (Hart ve Risley, 2003)

- Çalışmaya katılan çocuklar dört yaşına geldiğinde, düşük sosyoekonomik düzey grubundaki çocukların, yüksek sosyoekonomik düzey grubundaki çocuklardan kümülatif olarak 30 milyon sözcük daha az işittiği belirlenmiştir (Bkz. Şekil 2).

-

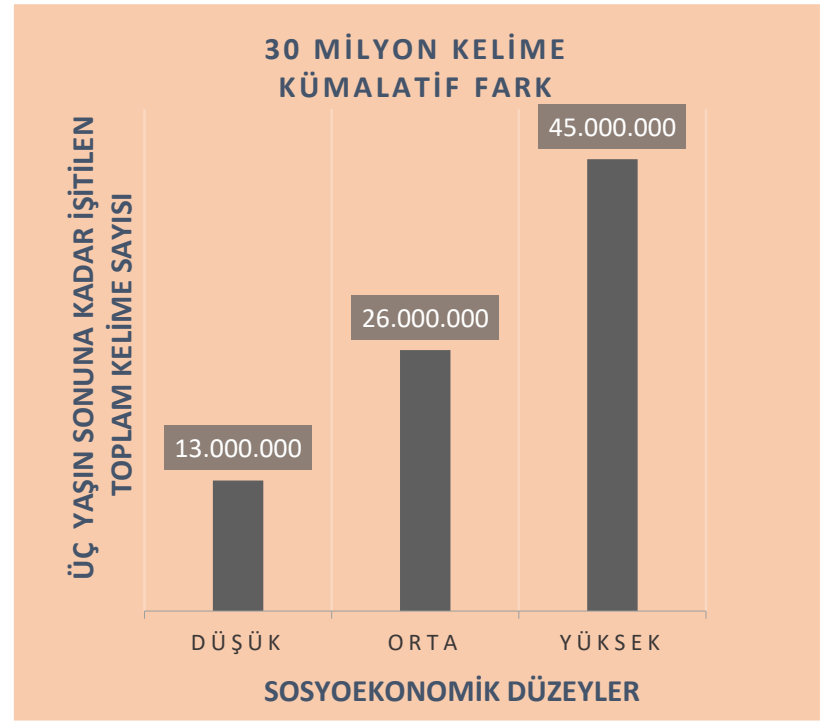

Şekil 2. Sosyoekonomik Düzeye Göre Üç Yaşın Sonuna Kadar İşitilen Toplam Sözcük Sayısı (Hart ve Risley, 2003).

- Çalışmanın boylamsal sonuçlarının belirlenmesi amacıyla çocuklar üçüncü sınıfa geçtiğinde 42 aileden 29 'u ile yeniden değerlendirmeye alınmıştır. Yapılan değerlendirme neticesinde düşük sosyoekonomik düzeye sahip ailelerin çocukların, dil gelişimi, okuduğunu anlama ve sözcük dağarcığı gibi alanlarda düşük performans sergilediği belirlenmiştir (Hart ve Risley, 2003).

Hart ve Risley'in $(1995,1999,2003)$ çalışmalarında, erken dönemde ebeveynlerin kullandığı sözcük sayısı ve konuşma biçimi gibi unsurların sosyoekonomik düzeye bağlı olarak önemli ölçüde farklıık gösterebileceği belirtilse de alanyazında bu çalışmaya yönelik çeşitli eleştirilerin de var olduğu görülmektedir. Eleştirmenler sıklıkla, metodolojik açıdan, 42 ailenin ayda sadece bir saat gözlendiği ve boylamsal süreçte sadece 29 çocuğun ilkokula giderken takip edildiği bir araştırmadan bu kadar güçlü sonuçların çıkarılıp çıkarılmayacağı konusunu irdelemektedir (Sperry, Sperry ve Miller, 2019; Suskind, 2018). Araştırma grubunda yer alan, düşük sosyoekonomik düzeydeki ailelerin etnik kökenin farklı olması durumuna dikkat çeken eleştirmenler, düşük sosyoekonomik düzeydeki ebeveynlerin ev ziyaretleri sırasında araştırmacıların varlığı, video kayıtları gibi faktörlere bağlı olarak sessiz kalabileceğini; eğitim düzeyi yüksek ebeveynlerin ise, ortamda bir gözlemci varken çocuğu ile daha 
fazla ilgilenerek, etkileşime girebilme ihtimalinin daha yüksek olabileceğini iddia etmektedir. Kültürel açıdan farklı sosyal düzeylerdeki ailelerin; ebeveynlik uygulamaları ve dilin kullanımı üzerinde farklııkların önemine dikkat çeken Miller ve Sperry (2012), yapılan çalışmalarda dilin öğrenildiği ve kullanıldığı kültürel bağlamların göz ardı edilmemesi gerektiği görüşünü savunmaktadır. Bu kapsamda, sosyoekonomik açıdan düşük düzeye sahip beş farklı bölgede yaşayan ailelerin doğal ortamlarındaki kayıtlarını inceledikleri çalışmada, çocukların işittiği sözcük sayısı farklılıklarının bölgeden bölgeye göre farklılık gösterebileceğini tespit etmiştir (Sperry vd., 2019). Yapılan çalışmalar neticesinde, erken dönemde işitilen sözcük sayısı farklılıkların yalnızca sosyoekonomik düzey farklııklarına bağlı olarak açıklanması durumunun sınırııık oluşturabileceğini belirtmiştir (Sperry vd., 2019).

Hart ve Risley'in (1995, 1999, 2003) araştırma bulgularına yönelik yapılan eleştiriler, sosyoekonomik düzey farklııklarına bağlı olarak erken dönemde çocukların işittiği sözcük sayısını konu alan yakın tarihli araştırma bulgularının gözden geçirilmesi gerekliliğini ortaya çıkarmaktadır. Bu noktada, yaşıyla uyumlu gelişim gösteren bebeklerin ve küçük çocukların doğal dil ortamını değerlendirilmesi amacıyla 329 aileyle gerçekleştirilen boylamsal bir çalışmada, 2 aydan 48 aya kadar çocuğun çevresindeki yetişkinlerin sözcük sayısı, bakım veren-çocuk etkileşimi, çocukların ses ve sözcük üretim sıklığı LENA ses kayıt cihazı kullanılarak kaydedilmiştir. Çalışmada, çocukların ses ve sözcük üretim sıklığının yaşla birlikte artarken, yetişkin sözcük sayılarının erken bebeklik sonrasında yaşa bağlı farklılık göstermediği tespit edilmiştir. Çalışmadan elde edilen bulgular incelendiğinde düşük sosyoekonomik düzeydeki çocukların daha yüksek sosyoekonomik düzeydeki akranlarıyla karşılaştıııldığında daha az sayıda sözcük ürettiği, yetişkin-çocuk etkileşiminin daha sınırlı olduğu ve yetişkinlerden daha az sayıda sözcük işittikleri görülmektedir. Tüm bu bulgulara ek çalışmada, çocuklar dört yaşına geldiğinde sosyoekonomik düzeyi düşük ve yüksek olan gruplar arasında işitilen sözcük sayısına bağlı olarak farklılıkların olduğu yalnızca dört milyon olduğu belirlenmiştir (Gilkerson vd., 2017). Farkas ve Beron (2004) ise sosyoekonomik düzeye bağlı olarak ortaya çıkan sözcük farkının yaşla birlikte arttığını, ilerleyen yıllarda özellikle okula hazırbulunuşluk düzeyi ve sözel dil becerilerinin gelişiminde sözcük farkına dayalı farklılıkların gözlenebildiğini belirtmiştir. Benzer şekilde, Durham, Farkas, Hammer, Tomblin ve Catts (2007) tarafından yapılan bir çalışmada, ailenin sosyoekonomik durumu ve erken çocukluk dönemi sözlü iletişim becerilerinin, ilkokul yıllarındaki akademik performans düzeyini önemli ölçüde açıkladığı belirlenmiştir. Çalışmada, ilköğretimdeki akademik başarının ilerleyen yıllardaki eğitim başarısını güçlü bir şekilde belirlediğini gösteren araştırma bulgularından hareketle, sosyoekonomik durumun kuşaklar arası iletiminin dilin iletimiyle ilişkili olduğu ve bu iletimin yaşamın ilk yıllarında ortaya çıktığı belirtilmiştir. Yaşamın ilk yıllarında işitilen sözcük sayısı, çocukların sözcük dağarcı̆ının gelişmesi açısından kritik bir öneme sahip olsa da bu durum dil gelişiminin sadece bir parçasını temsil etmektedir. Bu noktada, çocuğa sunulan dil ve ebeveynin konuşma biçiminin niteliği de sözcük dağarcığını geliştirmede oldukça önemli bir role sahip olduğu ifade edilebilir (Wasik ve Hindman, 2015).

\section{Sosyoekonomik Farklılıklar ve Çocuğa Yöneltilen Dil}

Ebeveynler, çocuklarının dil ve iletişim becerilerinin gelişiminde oldukça kritik bir konumda yer almaktadır. Dil öğreniminin ilk aşamalarından itibaren çocukların dil yetileri; kendilerine yöneltilen dilin özellikleri, ebeveyn davranışları ve uygun çevresel faktörlerin etkisiyle birlikte şekillenmektedir (Demir ve Küntay, 2013). Yetişkinlerin çocuklarıyla olan konuşmalarındaki etkileşimler, çocukların alıcı ve ifade edici dil becerilerini destekleyici yaklaşımlar olarak ele alınmaktadır. Yetişkinin bu etkileşim sırasında, çocuğun dil ve gelişimsel özelliklerine göre dil girdilerini düzenlemesi "çocuğa yöneltilen dil (child-directed speech)" olarak adlandırılmaktadır. Çocuğa yöneltilen dilin içerdiği özellikler temel olarak "çocuğun gelişimsel düzeyine uygun dil bilgisel yapıların kullanımı, tekrarlar içeren yavaş konuşma hızı, ifadelerin genişletilmesi, kısa cümlelerin kullanımı, çocuğun ilgilendiği nesneler ve olaylar hakkında konuşma, çocuğun konuşmasındaki vurgu, ritim gibi özelliklerin taklidi, çocuğun cümlelerini tekrarlama ve çocuğa sorular yöneltme" şeklindedir (Turan, 2012). Bu kapsamda, ebeveynin, erken yaşlardan itibaren çocuğuyla konuşma sıklığı, çocuğunun hareketlerine ve dil öncesi çıkardığı seslere duyarlı olarak söylediği sözcükler veya 
cümlelerle ilişkili olarak ona cevaplar vermesi, yorumlar yapması, cevabı evet/hayır olan sorular yerine açık uçlu sorular yöneltmesi, anlamlı ve dil bilgisi kurallarına uygun cümleler kurması, çocuğun sözcük dağarcığının gelişim hızı başta olmak dil ve iletişim becerilerinin gelişimini etkilemektedir(Cengiz, 2013; Muslugüme, 2016).

Erken dönemde ebeveynlerinden zengin içerikte dil işiten bebekler, hızı gelişen dili işlemleme becerileri sayesinde yeni sözcükleri de daha hızlı öğrenebilmektedir (Weisleder ve Fernald, 2013). Huttenlocher ve arkadaşlarının (1991), erken dönemde sözcük dağarcığının gelişiminde konuşmaya maruz kalmanın rolünü tespit etmek amacıyla benzer sosyoekonomik düzeye sahip anneler ve bebeklerini 14-26 ay arasında çeşitli zaman aralıklarında ev ortamında gözlemlediği çalışma bulguları, annelerin çocuklarıyla olan iletişiminde kullandıkları sözcük çeşitleri arasında farklııklar olduğunu göstermektedir. Çalışma sonucunda, annesinden daha fazla sayıda ve çeşitlilikte sözcük işiten bebeklerin; 16 aylıkken 33, 20 aylıkken 131, 24 aylıkken 295 daha farklı sözcük üretebildiği tespit edilmiştir. Bu bulgu üzerinden, ebeveynlerin çocuklarıyla iletişimi sırasında kullandığı sözcüklerin çeşitliliğinin, çocukların sözcük dağarcığı üzerinde önemli bir role sahip olduğu düşünülebilir. Nitekim, Hurtado, Marchman ve Fernald (2008) tarafından ebeveynlerin konuşmasındaki değişimin çocukların dil gelişimi üzerine etkisinin incelendiği boylamsal araştırmadan elde edilen bulgular; ebeveynin konuşma çeşitliliğin, çocuğun ilerleyen aylardaki sözcük tanıma ve sözcük dağarcığını olumlu yönde etkilediğini göstermektedir.

Alanyazında sosyoekonomik düzeye bağlı olarak ebeveynlerin çocuğa yönelttiği dilin miktarı arasında farklılıkların da olduğu göze çarpmaktadır (Hart ve Risley, 1995; Hoff-Ginsberg, 1991; Hoff, 2003a, 2003b, 2006; Hoff ve Naigles, 2002). Yüksek sosyoekonomik düzeye sahip ebeveynlerin, çocuklarıyla konuşurken daha çeşitli sözcükler kullandığı, çocuklarının sözcük dağarcığının genişlemesine katkı sağladığı (Hoff, 2003a, 2003b; Hoff ve Naigles, 2002), sosyoekonomik açıdan dezavantajlı ve eğitim düzeyi düşük ebeveynlerin çocuklarıyla daha az konuşma ve farklı sözcük kullanma eğiliminde olduğunu belirten çalışmalar mevcuttur (Hart ve Risley, 1995; Hoff-Ginsberg, 1991). Bu doğrultuda, ekonomik açıdan dezavantajı ortamda yetişen ve daha sınırlı konuşma girdisiyle karşılaşmanın uzun dönemde çocuklar arasında farklılıkları da beraberinde getirebileceği ifade edilebilir. Düşük veya yüksek sosyoekonomik ortamda yetişme durumuna bağlı olarak bebeklerin, sözcük ve dili işlemleme becerileri arasındaki farklııklar; gelişimsel açıdan 18 ay itibariyle belirginleşmekte (Fernald vd., 2013) ve erken dönemde sözcük bilgisi ve sözcük dağarcığı farklılıkları, ilköğretim yıllarında da devam ederek özellikle çocukların okuma başarısı üzerinde uzun süreli olumsuz etkilere neden olmaktadır (Snow, Pan, Imbens-Bailey ve Herman, 1996). Bu noktada alanyazında, ebeveynlerin günlük rutinler (yemek yeme, oyun oynama, giyinme vb.) sırasında çocuklarına yönelttiği dile kıyasla, çocuklarına kitap okurken kullandığı dilin birçok açıdan daha çeşitli olduğu, hikayelerin çeşitli sözcükler ve nadir sözcükler içerdiği belirtilmektedir (De Temple ve Snow, 2003; Weizman ve Snow, 2001). Bu nedenle sosyoekonomik düzeye bağlı olarak erken dönemden itibaren ebeveynlerin kitap okuma uygulamaları arasında farklılıkların da ele alınması gerekmektedir.

\section{Sosyoekonomik Farklılıklar ve Paylaşımlı Kitap Okuma}

Ebeveynler, kitap okuma uygulamaları yoluyla çocuklarına dil açısından zengin bir ortam oluşturabilmektedir (Demir ve Küntay, 2013; Turan ve Akoğlu, 2014). Whitehurst ve Lonigan (1998), çocukların sözcük dağarcığı gelişimini destekleyici en etkili aktivitelerin başında paylaşımlı kitap okuma etkinliklerinin geldiğini belirtmektedir (Lonigan, Schatschneider ve Westberg, 2008). Paylaşımlı kitap okuma, kitap okuma sırasında yetişkinle çocuk arasında ortaya çıkan etkileşim sürecini içermekte olup çocukların dil ve okuryazarlık becerilerini desteklemektedir (Ezell ve Justice, 2005; Turan, 2020). Paylaşımlı kitap okuma sırasında yetişkin; çocuğun dikkatini kitapta yer alan resimlere, yazılara, sözcük anlamlarına yönlendirebilmektedir. Hikayedeki olaylar ve durumlar hakkında çocuğa sorular sorabilmekte, bilgi verebilmekte, var olan bilgiyi genişletebilmekte, bilgiyi günlük yaşam deneyimleriyle ilişkilendirebilmektedir. Bu süreçte önemli olan, okunan metnin tüm yönlerine çocuğun dikkatini çekmek amacıyla bir veya daha fazla etkileşime dayalı tekniklerin sistematik olarak kullanılmasıdır. Paylaşımlı kitap okuma esnasında, yetişkinler tarafından kullanılan 
etkileşime dayalı yöntemler yoluyla çocuklar "aktif katılımcılar" hâline gelmektedir (What Works Clearinghouse, 2015).

Paylaşımlı kitap okuma üzerine yapılan çalışmalar kitap okumanın; sözcük bilgisi (Farrant ve Zubrick, 2013), konuşma ve anlatım becerileri (Reese, 1995), ilerleyen yaştaki okuma becerileri (Bus, Van ljzendoorn ve Pellegrini, 1995), yazı farkındalığı (Justice ve Pullen, 2003), dil bilgisi (ValdezMenchaca ve Whitehurst, 1992), sesbilgisel farkındalık (Chow, McBride-Chang, Cheung ve Chow, 2008; Lefebvre, Trudeau ve Sutton, 2011) gibi birçok erken dil becerisini olumlu yönde etkilediğini göstermektedir. Paylaşımlı kitap okuma uygulamasıyla çocukların erken dönemde sözcüklere olan maruziyeti artmaktadır (Turan ve Topcu, 2018). Logan, Justice, Yumus ve Chaparro-Moreno'ya göre (2019), her gün çocuklarıyla birlikte bir resimli çocuk kitabı okuyan ebeveynler, çocuklarını her yıl yaklaşık 78.000 sözcüğe maruz bırakmaktadırlar. Yaşamın ilk beş yılı boyunca okuryazarlık açısından zengin bir ortamdan gelen çocukların, ev ortamında hikaye kitabı hiç okunmayan çocuklardan kümülatif olarak 1.4 milyondan daha fazla sözcük duydukları iddia edilmektedir (Logan vd., 2019).

İşitilen sözcük sayısının erken dönem dil becerileri açısından oldukça önemli olduğu düşünüldüğünde alanyazında sosyoekonomik düzeye bağlı olarak ebeveynlerin çocuklarıyla gerçekleştirdikleri paylaşımlı kitap okuma uygulamalarında niceliksel (kitap okuma sıklığı) ve niteliksel (kitap okuma sırasında ebeveynin iletişim davranışları ve kitap okuma stratejileri gibi) açıdan birtakım farklııkların olduğu göze çarpmaktadır (Işıkoğlu Erdoğan, 2016; Alice A. Kuo, Todd M. Franke, Michael Regalado ve Neal Halfon, 2004; Rodríguez, Hines ve Montiel, 2009; Shahaeian vd., 2018). Berkule, Dreyer, Huberman, Fierman ve Mendelsohn (2007) tarafından yapılan bir çalışmada, yenidoğan bebeği olan sosyoekonomik olarak dezavantajlı olan risk altındaki annelerin çoğu, bebekleriyle paylaşımlı kitap okuma uygulaması yapma planlarının olmadığını ve evlerinde çocuk kitabı bulunmadığını bildirmiştir. Kuo, Franke, Regalado ve Halfon (2004), düşük sosyoekonomik düzeye sahip annelerin \%28'inin çocuklarıyla haftada üç günden daha az paylaşımlı kitap okuma uygulaması yaptığını belirtmektedir. Ülkemizde yapılan bir çalışmada da, eğitim ve sosyoekonomik düzeyi düşük ebeveynlerin çocuklarına daha az kitap okuduğu belirlenmiştir (Işıkoğlu Erdoğan, 2016). Rodríguez ve arkadaşları (2009) tarafından yapılan bir çalışmada, kitap okuma sırasında, orta sosyoekonomik düzeydeki ebeveynlerin olumlu geri bildirim kullanma, sorular sorma gibi etkileşime dayalı okuma stratejilerini düşük sosyoekonomik düzeydeki ebeveynlerden daha sık kullanma eğiliminde olduğu görülmektedir. Paylaşımlı kitap okuma uygulamaları sırasında etkileşime dayalı yöntemlerin sınırlı düzeyde kullanılması durumu; çocukları pasif dinleyici konumuna getirebilmektedir. Sénéchal, Thomas ve Monker (1995) tarafından yapılan bir çalışmada, kitap okuma uygulamaları sırasında pasif dinleyici olan çocukların, aktif katılan çocuklardan daha az sayıda sözcük öğrendiği belirtilmektedir. Bu bulgu üzerinden kitap okuma uygulamalarına aktif birer katılımcı olarak etkileşim kurmanın erken dil becerilerininin gelişimi sürecinde önemli bir role sahip olduğu ifade edilebilir.

Erken dönemde dil ve okuryazarlık açısından zengin ortamlarda bulunan çocukların, ilerleyen yıllarda akademik açıdan daha başarılı olabileceği düşünülmektedir. Shahaeian ve arkadaşları (2018) tarafından paylaşımlı kitap okumanın boylamsal etkilerinin incelendiği çalışmada, paylaşımlı kitap okuma ile ortaya çıkan erken okuryazarlık ve akademik becerilerin ilerleyen yaşlarda çocukların akademik başarılarıyla ilişkili olduğu bulgulanmış olup, erken dönemde yüksek sosyoekonomik düzeye sahip ebeveynlerin çocuklarıyla daha sık paylaşımlı kitap okuma uygulamaları gerçekleştirdiği belirlenmiştir. Bu bulgu üzerinden, sosyoekonomik açıdan dezavantajı olan çocukların ilerleyen yıllarda, okula hazırbulunuşluk açısından da risk altında olduğu belirtilebilir. Sosyoekonomik açıdan dezavantajı olan çocukların gelişimsel açıdan en üst potansiyele ulabilmesi için erken dönemde dil ve okuyazarlık becerilerinin desteklenmesi gerektiği düşünülmektedir. Bu doğrultuda, erken dönemde gelir eşitsizliği sonucu oluşabilecek risk faktörleriyle mücadele etmek ve risk altındaki çocukların gelişimini optimum seviyeye ulaştırmak amacıyla ebeveynleri güçlendirmeyi amaçlayan ulusal ve uluslararası düzeydeki sosyal girişim örneklerinden bazıları ele alınacaktır.

\section{Okuyan Bir Gelecek Projesi}

Okuyan Bir Gelecek Projesi, gelişimin erken dönemlerinden itibaren çocuklara kitap okumanın önemi konusunda toplumda farkındalık yaratmak amacıyla Anne Çocuk Eğitim Vakfı (AÇEV) 
tarafından geliştirilmiştir. Çocukların kitaplarla buluşabilmesini sağlamak amacıyla hayata geçirilen projede, AÇEV'in erken çocukluk uzmanlarının seçtiği nitelikli çocuk kitaplarına ünlü sanatçılar, uzmanlar ve yazarlar ses vermektedirler. Okunan her kitaplarla çocukların yeni kelimeler öğrenebileceği belirtilmektedir. Ayrıca platform üzerinden yapılan bağışlar yoluyla, kitaplara erişimi olmayan çocukların Okuyan Bir Gelecek setleriyle buluşturulmaktadır. Bu setlerin içerisinde, resimli çocuk kitapları, oyun etkinlik önerileri, resim defteri, kuru boya, oyun hamuru, geometrik şekil oyunu, bilim çocuk dergisi yer almaktadır. AÇEV gönüllü eğitimcileri gönderilen eğitsel materyallerin kullanımı hakkında ebeveynlere rehber olmak amacıyla telefon görüşmeleri gerçekleştirmektedir (AÇEV, t.y.).

\section{Bir Milyon Kitap Projesi}

Bir Milyon Kitap Projesi, doğumdan itibaren kitap okumanın önenimi anlatmak ve evinde kitap olmayan çocuklara ilk kitaplarını hediye etmek amacıyla ülkemizde başlatılan sosyal girişim projesidir. Proje IIlk Kitabım seti ve Büyüyorum setinden oluşmaktadır. Kitap setlerinin sosyoekonomik açıdan dezavantajı olan 1 milyon çocuğa ulaştırılması hedeflenmektedir. Doğumdan itibaren ebeveynlerin çocuklarıyla diyaloğa dayalı bir iletişim kurmalarına zemin hazırlamak amacıyla ailelerin evlerine gönderilen ilk kitapların, ebeveynlerin çocuklarıyla daha fazla kaliteli zaman geçirmesine, iletişim kurmasına, alıcı ve ifade edici dili destekleyici yaklaşımlarda bulunmasına katkı sağlayacağı düşünülmektedir (1 Milyon Kitap, 2019).

\section{Raising Readers}

Raising Readers, doğum deneyiminin rutin bir parçası olarak beş yaşına kadar Amerika'daki Maine eyaletinde yaşayan tüm çocukları kitaplarla buluşturma hedefiyle Libra Foundation (Libra Vakfı) fonu ile oluşturulan kitap kampanyasıdır. Ebeveynlerin herhangi bir başvuru formu doldurmasına gerek kalmadan belirli aralıklarla $(2,4,6,9,12,15,18,24,36,48$ ay) birinci basamak sağlık hizmeti profesyonelleri tarafından yapılan rutin sağlık kontrolleri ve ev ziyaretleri sırasında çocuklara kitaplar verilmektedir. Maine eyaletindeki tüm doğum hastenelerinin ve birinci basamak sağlık hizmeti sağlayıcılarının neredeyse tamamı Raising Readers girişimine katılmaktadır. Erken okuryazarlık sürecini, doğumdan itibaren sağlık ortamlarına entegre eden Raising Readers, aileleri çocuklarına kitap okumaya teşvik ederek çocukların beyin gelişimi ve okuryazarlık becerilerini güçlendirmektedir. 2000 yııından günümüze kadar her yaş ve aşamayı yansıtacak şekilde seçilen üç milyonun üzerinde çocuk kitabı çocuklara iletilmiş olup, 290.000 çocuk beş yaşına geldiğinde kendisine ait 12 kitaptan oluşan küçük bir ev kütüphanesine sahip olmuştur (Raising Readers, 2020).

\section{Too Small To Fail}

Too Small To Fail'in "Talking is Teaching" kampanyası, sosyo ekonomik düzeyi düşük ve yüksek olan ailelerin çocuklarının sözcük dağarcığı arasındaki eşitsizliğini önleyebilmek ve erken dönemde dil gelişiminin önemini teşvik etmek amacıyla kar amacı gütmeyen Gelecek Nesil (Next Generation) ve Clinton Vakfı'nın (Clinton Foundation) ortak girişimidir. Erken dönemde ebeveynlerin çocuklarıyla basit ve gündelik etkileşimler yoluyla çocuklarının yaşam boyu öğrenmeleri için güçlü temeller oluşturabileceği görüşünden hareketle, ebeveynleri ve bakıcıları doğumdan itibaren çocuklarıyla "konuşmak", "okumak" ve "şarkı söylemek" için motive ederek kamu bilinci oluşturmayı amaçlayan bir eylem kampanyasıdır. Kampanyada, erken dönemde dil açısından zengin ortamlar oluşturulmasının kritik önemi hususunda ebeveynlerin farkındalık düzeyinin arttırıması hedeflenmektedir. Ebeveynlerin farkındalık düzeyinin artması sonucu, sözcük dağarcı̆̆ı eşitsizliğinin önlenerek, çocukların potansiyellerinin en üst seviyeye ulaşılabileceği öngörülmektedir (Too Small To Fail, 2014).

\section{Vroom}

Yaşam boyu öğrenme için güçlü bir temel oluşturmak amacıyla yaşamın ilk beş yılından daha iyi bir zaman olmadığına vurgu yapan "Vroom" Bezos Aile Vakfı tarafından 2015 yılında kurulmuştur. Vroom; sinirbilim, psikoloji, ebeveynlik ve erken çocukluk gelişimi alanlarındaki uzmanlar ve 
akademisyenlerin katkılarıyla geliştirilmiş olup günümüze kadar 37 eyalette ve dünyanın 6 ülkesinde 1.500.000 aileyi etkileyen Vroom, etki alanını arttırmaya devam etmektedir. Erken dönemde, ebeveyn-çocuk arasındaki etkileşimi güçlendirmek ve ebeveynlerin çocuklarının yürütücü işlevlerini teşvik eden yaşam becerilerini destekleyebilir konuma getirmek amacıyla Vroom tarafından çeşitli araçlar ve uygulamalar geliştirilmektedir. Bu kapsamda, ebeveynlere ve çeşitli topluluklara yönelik olarak uzmanlar tarafından geliştirilen Vroom mobil uygulaması dikkat çekmektedir. Vroom uygulamasını ücretsiz olarak indirebilen ebeveynler, ilk olarak çocukların yaşlarını belirtmektedir. Bu şekilde uygulama, ebeveynlere, çocukların gelişimsel açıdan gereksinimlerine yönelik olarak öneriler ve bilgiler sunmaktadır. Uygulamada, uyku, yemek yeme, banyo yapma gibi günlük rutinler sırasında da çocukların beyin gelişimini ve yönetici işlevleri desteklemek amacıyla geliştirilmiş "Günlük Vroom" bölümü yer almaktadır. Vroom aktiviteleri yoluyla erken dönemde çocukların beyin gelişiminin desteklenmesi amaçlanmaktadır (Vroom, t.y.).

\section{Providence Talks}

Çocukların günde yaklaşık 21.000 sözcük duyması gerektiğini vurgulayan Providence Talks, sosyoekonomik düzey farklılığına dayalı sözcük dağarcığı eşitsizliğini önlemek amacıyla geliştirilen ev temelli erken müdahale programıdır. Program kapsamında ebeveynlerin çocuğun erken dil çevresini zenginleştirilmesine kakı sağlamak amacıyla, LENA teknolojisi (ebeveyn-çocuk etkileşimlerini izlemek ve ebeveynlere sistematik geri bildirim vermek üzere geliştirilen kayıt sistemi teknolojisi) ve ücretsiz olarak iki haftada bir ebeveyn koçluğu sisteminden faydalanılmaktadır. Providence Talks erken müdahale programının pilot çalışmasına katılan ebeveynlerin çocukların büyük bir çoğunluğunun sağlıklı bir beyin gelişimi için ihtiyaç duyduklarından çok daha az sözcük duydukları tespit edilmiş olup ilk ebeveyn koçluğu oturumlarının tamamlanmasının ardından ailelerin ev ortamında konuştuğu sözcükleri \%50 oranında arttırdığı belirlenmiştir. Günde ortalama 8.000 sözcük konuşan ebeveynlerin ilk oturumun ardından 12.000 sözcüğe yükselttiği tespit edilmiş olup pilot çalışmanın olumlu etkileri sonucunda müdahale programı tüm şehirde uygulanabilir bir hale getirilmiştir. Providence Talks erken müdahale programıyla ebeveynlerin kritik dönemde güçlendirilmesi yoluyla, 30 milyon sözcük boşluğunun erken dönemde kapatılabileceği ve sözcük dağarcığı eşitsizliğinin önlenebileceği belirtilmektedir. Bloomberg Philanthropies' 2012 Mayors Challange büyük ödülünü kazanan Providence Talks programının etkililiğini ölçmek için Brown Üniversitesi ile iş birliği yapılmaktadır (Providence Talks, t.y.)

\section{Educare}

Ounce of Prevention ve Buffett Early Childhood fonları ile 2003 yılında oluşturulan Educare modeli, erken çocukluk gelişimi, eğitimi, sosyal hizmet gibi alanlarda yapılan araştırmalara dayanmakta olup modelin temel amacı erken çocukluk dönemi için program, mekân, ortaklık ve platform sunmaktır. Educare, sosyoekonomik açıdan dezavantajlı olan çocuklara doğumdan beş yaşına kadar tüm gün ve yıl boyu süren öğretim sunarak çocukları okula hazır hale getirmeyi hedeflemektedir. Program, erken çocukluk eğitimcileri tarafından uygulanmaktadır. Eğitimciler, çocukları yalnızca okulda desteklemekte kalmaz aynı zamanda çocukların gelişimini en üst potansiyele ulaştırmak üzere ebeveyn-çocuk etkileşimini desteklemek amacıyla ebeveynlere de rehberlik etmektedir. Ayrıca, çocukların ve ailelerin birinci basamak sağlık hizmetlerine ulaşmalarını sağlamak üzere girişimlerde bulunmaktadır. İki yıl ve üzerinde Educare modelinden faydalanan risk altındaki çocukların büyük bir çoğunluğunun akademik, sosyal ve duygusal açıdan anaokuluna hazır olduğu gözlenmiştir. Educare erken öğrenme programlarına risk altındaki her çocuğun ulaşabilmesini sağlamak amacıyla ekip üyeleri, yerel ve ulusal boyutta politikalar geliştirilmesi yönünde savunuculuk yapmaktadır (EDUCARE, 2003).

\section{The Thirty Million Words (30 Milyon Kelime)}

30 Milyon Sözcük girişimi, doğumdan üç yaşına kadar bebeklerin erken dil ortamlarını zenginleştirmek ve düşük gelirli ailelerden gelen çocuklar ve yüksek gelirli ailelerden gelen çocuklar arasındaki sözcük boşluğunu azaltmak amacıyla ebeveynlere yönelik Dana Suskind tarafından 
geliştirilen bilimsel bir müdahale programıdır. Beyin gelişimi için kritik öneme sahip olan bebeklik döneminde erken dil çevresini zenginleştirilmesinin önemli olduğunu vurgulayan girişimde "kavrayın", "konuşun" ve "karşlıklı yapın" olmak üzere ebeveynler tarafında kullanılabilecek "Üç K" stratejileri geliştirilmiştir. Ebeveynin çocuğunun neye odaklandığını anlaması için bilinçli bir çaba göstermesi ve bununla ilgili olarak çocuğuyla konuşması olarak adlandırılan "kavrayın" stratejisi yoluyla ebeveyn, çocuğunun ne yaptığının farkına vararak ve çocuğuyla kurduğu ilişkiyi zenginleştirerek çocuğunun beyin gelişimine katkıda bulunmaktadır. Kavrama ile giden "konuşun" stratejisi, ebeveynin çocuğuyla birlikte özellikle çocuğun odaklandığı durumla ilgili konuşmasını içermektedir. "Karşııkı Yapın" stratejisi ise, ebeveyn-çocuğun aktif olarak katıldığı karşııklı sohbet anlamına gelmektedir. Ebeveyn-çocuk arasındaki etkileşimi güçlendirmek ve çocuğun dil çevresini zenginleştirmek amacıyla geliştirilen Üç $K$ stratejilerinin, çocuklara optimum fayda sağlayacak nitelikte olduğu öngörülmektedir. 30 Milyon Sözcük girişimi programının etkililiğini değerlendirmek üzere LENA dijital ses kaydedicisi sistemi kullanılmış olup, ebeveynlerin çocuklarıyla konuşma miktarında anlamlı artışlar olduğu gözlenmiştir (Suskind, 2018).

\section{Start Young}

The Family Conservancy tarafından geliştirilen Start Young projesi, Amerika Wyandotte ilçesinde, çocuk bakımını iyileştirmek ve çalışan ailelerin çocuklarının yüksek kaliteli çocuk bakım hizmetlerine erişimini arttırmak amacıyla tasarlanan üç yıllık pilot çalışması devam eden kamu-özel iş birliğidir. Start Young projesi, çalışan ebeveynlerin çocuklarının bakımı için yüksek kaliteli bakım merkezlerine uygun maliyetlerle erişebilmesini desteklemek için çalışmaktadır. Çocuk sahibi olan ebeveynlerin iş gücüne katılımını destekleyen Start Young Projesi sayesinde yüksek kaliteli çocuk bakım hizmetlerine erişebilen erken beyin gelişimi optimum seviyeye ulaşabilen çocukların okul yaşantısında daha başarılı olacağı öngörülmektedir. Projenin ilk yılında, Wyandotte ilçesinde 199 yeni çocuk bakımı alanı açılmış, 360 çocuk gelişimsel açıdan değerlendirilmiş, 71 öğretmen ve yönetici gelişimsel izlem ve takip yapabilmek üzere eğitilmiş, çocuk bakım merkezlerinde çalışabilmek üzere uzmanlar istihdam edilmiş olup çalışan ailelerin \%40'ına hizmet edebilme kapasitesine ulaşmıştır (The Family Conservancy, t.y.).

\section{Sonuç ve Öneriler}

Dil gelişimi, doğumdan itibaren hızlı bir şekilde başlayarak, yaşam boyu devam eden bir süreçtir. Çocuğun çevresiyle olan etkileşimi, özellikle ilk iletişimde bulunduğu aile ortamı, dil gelişiminde kritik bir konumdadır (Muslugüme, 2016). Dil gelişimini şekillendiren en önemli çevresel faktörlerden biri, erken dönemde çocuğa yöneltilen dil olarak karşımıza çıkmakta olup alanyazında ebeveynlerin sosyoekonomik düzeye bağlı olarak çocuklarına yönelttiği dilin niceliği ve niteliği arasında farklılıklar görülebilmektedir. Bu kapsamda bu çalışmada ilk olarak; erken dönemde işitilen sözcük sayısı başta olmak üzere ebeveynin çocuğa yönelttiği dil ve paylaşımlı kitap okuma gibi ebeveyn-çocuk etkileşiminde sosyoekonomik düzeye bağlı olarak oluşabilecek kaynaklanan farklııklar gözden geçirilmiştir. Hart ve Risley (1995) çalışmalarında, ebeveynlerin kullandığı sözcük sayısıyla ve konuşma biçiminin sosyoekonomik düzeye bağlı olarak farklılık gösterdiği, düşük sosyoekonomik düzey grubundaki çocukların dört yaşına geldiğinde, yüksek sosyoekonomik düzey grubundaki çocuklardan kümülatif olarak 30 milyon sözcük daha az işittiği görülmektedir. Çalışmanın boylamsal sonuçları değerlendirildiğinde, erken dönemde ebeveynlerin çocuğa yönelttiği dil ve çocukların işittikleri sözcük sayısıyla; çocukların konuşma biçimleri arasında ilişki olduğu gözlenmiştir (Hart ve Risley, 2003). Suskind (2018), ayda sadece bir saat ve 42 çocuğun gözlemlendiği bir çalışmadan, bu kadar güçlü sonuçların çıkarılıp çıkarılamayacağının önemli bir tartışma konusu olduğunu ifade etmektedir. Ancak alanyazında; sosyoekonomik açıdan dezavantajlı ailelerde sözel uyaranların sosyoekonomik açıdan avantajlı olan ailelere göre daha kısıtlı olduğu belirtilmektedir (Hoff, 2013; Huttenlocher, Vasilyeva, Cymerman ve Levine, 2002; Huttenlocher, Vasilyeva, Waterfall, Vevea ve Hedges, 2007). Erken dil maruziyeti ve sözel beceriler arasındaki ilişkinin altında yatan nöral aktivasyonların rolünün incelendiği yakın tarihli bir çalışmada, çocuk ve yetişkin arasında sıra almaya dayalı iletişimin, sosyoekonomik düzey ile sözel yetenek ilişkisine önemli ölçüde aracılık ettiği, daha 
fazla konuşma sırası alan çocukların, dil işleme sırasında sol alt frontal bölgesinde (Broca Alanı) daha fazla aktivasyon sergilediği bulgulanmıştır (Romeo vd., 2018). Bu çalışma, çocuğa yöneltilen dilin niteliksel yönlerinin ve Broca alan aktivasyonunun, erken dil becerilerinde sosyoekonomik eşitsizliklerin altında yatan hem çevresel hem de sinirsel mekanizmaların önemini göstermektedir. Bu doğrultuda, sosyoekonomik düzeye bağlı olarak ebeveynlerin kullandığı iletişim biçimleri arasındaki farklııkların, başta erken çocukluk olmak üzere çocukların ilerleyen yaşantısını olumsuz yönde etkileme riskinin dikkate alınması ve çeşitli risk faktörleriyle baş edebilmek için düşük sosyoekonomik düzeye sahip olan çocukların erken dönem dil becerilerinin desteklenmesi amacıyla ebeveynlerin güçlendirilmesi gerektiği düşünülmektedir. Bu kapsamda bu çalışmanın ikinci aşamasında, erken dönemde gelir eşitsizliği sonucu oluşabilecek risk faktörleriyle mücadele etmek ve risk altındaki çocukların gelişimini optimum seviyeye ulaştırmak amacıyla ebeveynleri güçlendirmeye yönelik ulusal düzeyde Okuyan Bir Gelecek Projesi, Bir Milyon Kitap Projesi ve uluslararası düzeyde Raising Readers, Too Small To Fail, Vroom, Providence Talks, Educare, The Thirty Million Words (30 Milyon Kelime), Start Young gibi erken çocukluk dönemi organizasyonları incelenmiştir.

Sonuç olarak, tüm çalışmalar ve çalışmalardan elde edilen bulgular değerlendirildiğinde, doğumdan itibaren ebeveynlerin çocuklarıyla olan iletişimi ve etkileşimi dil ve beyin gelişiminin optimum seviyeye ulaşabilmesine katkı sağlamaktadır. Dil bakımından zengin bir çevre; dil ve okuryazarlık, akıl yürütme, matematik, sosyal beceriler gibi sözel ve sözel olmayan becerilerin temelini oluşturmaktadır. Erken yaşlardaki dil ortamı, yaşam boyu öğrenme sürecinde çocuklar açısından kritik bir öneme sahiptir. Araştırmalar, sosyoekonomik düzeydeki farklılıklara bağlı olarak işitilen sözcük sayısı, kitap okuma yöntemleri, işitilen sözcüklerin nitelik ve nicelikleri arasında farklııkların olduğunu ve bu farklııkların çocukların ilerleyen yaşantısını olumsuz yönde etkileyebileceğini göstermektedir. Bu çerçevede, risk altındaki çocukların erken dil ortamını zenginleştirmek, dil ve beyin gelişimini desteklemek amacıyla sosyoekonomik açıdan dezavantajı olan ebeveynlerin desteklenmesi gerekmektedir. Erken iletişim becerilerinin, ilerleyen yıllarda dil gelişimi, erken okuryazarlık, okula hazır olma ve akademik beceriler üzerine etkileri düşünüldüğünde, risk altındaki ebeveynleri desteklemeye yönelik olarak başlatılan sosyal girişimlerin ve geliştirilen müdahale programlarının özellikle ülkemizde sınırlı olduğu görülmektedir. Sosyoekonomik açıdan dezavantajlı olan çocukların dil ve beyin gelişimini desteklemek amacıyla ebeveyn-çocuk etkileşimini güçlendirmeyi hedefleyen bu girişimlerin erken dönemde sözcük dağarcı̆̆ı eşitsizliğini önleme noktasında önemli bir role sahip olduğu düşünülmektedir. Bu doğrultuda, uluslararası düzeyde geliştirilen sosyal girişimlerin uzun vadede çocuklar ve ebeveynler üzerindeki etkileri göz önüne alındığında, ülkemizde de doğumdan itibaren risk altındaki ailelerin gereksinimleri doğrultusunda yapılandırılmış koruyucu ve ebeveynleri destekleyici daha fazla sayıda sosyal girişimlerin başlatılması önerilmektedir.

\section{Araştırma ve Yayın Etiği}

Bu çalışmada "Yükseköğretim Kurumları Bilimsel Araştırma ve Yayın Etiği Yönergesi" kapsamında uyulması belirtilen tüm kurallara uyulmuştur. Yönergenin ikinci bölümü olan "Bilimsel Araştırma ve Yayın Etiğine Aykırı Eylemler" başlığı altında belirtilen eylemlerden hiçbiri gerçekleştirilmemiştir.

\section{Yazarların Katkı Oranı}

Bu çalışmaya birinci ve ikinci yazar eşit oranda katkı sağlamıştır.

\section{Çıkar Çatışması}

Bu çalışmanın hazırlanmasında ve yayınlanmasında çıkar çatışması teşkil edebilecek bir durum ve ilişki bulunmamaktadır. 


\section{Kaynaklar}

AÇEV (t.y.). Okuyan Bir Gelecek Projesi. Erişim adresi: https://okuyanbirgelecek.acev.org/

Anlar, B., Serdaroğlu, A. ve Yakut, A. (2008). Gelişimsel çocuk nörolojisi. Ankara: Hacettepe Üniversitesi Hastaneleri Basımevi.

Berkule, S. B., Dreyer, B. P., Huberman, H. S., Fierman, A. H., \& Mendelsohn, A. L. (2007). Attitudes about shared reading among at-risk mothers of newborn babies. Ambulatory Pediatrics: The Official Journal of the Ambulatory Pediatric Association, 7(1), 45-50.

Bir Milyon Kitap (2019). 1 Milyon Çocuğun Illk Kütüphanesini Birlikte Kuruyoruz! Erişim adresi: https://1milyonkitap.com/

Bus, A. G., Van Ijzendoorn, M. H., \& Pellegrini, A. D. (1995). Joint book reading makes for success in learning to read: A meta-analysis on intergenerational transmission of literacy. Review of Educational Research, 65(1), 1-21.

Cengiz, Ö. (2013). Türk annelerin çocuklarına kitap okurken kullandıkları dil. Hacettepe Üniversitesi Edebiyat Fakültesi Dergisi, 30(1), 97-114.

Chow, B. W.-Y., McBride-Chang, C., Cheung, H., \& Chow, C. S.-L. (2008). Dialogic reading and morphology training in Chinese children: effects on language and literacy. Developmental Psychology, 44(1), 233.

Cirhinlioğlu, F. G. (2015). Çocuk gelişimi ve ruh sağlığı. Ankara: Nobel Akademik Yayıncılık.

Connell, C., \& Prinz, R. (2002). The impact of childcare and parent-child interactions on school readiness and social skills development for low-income African American children. Journal of School Psychology, 40(2), 177-193.

De Temple, J., \& Snow, C. E. (2003). Learning words from books. In A. v. Kleeck, S. A. Stahl, \& E. B. Bauer (Ed.), On reading books to children: Teachers and parents (s. 29-48). Mahwah, NJ, US: Lawrence Erlbaum Associates Publishers.

Demir, Ö. E. ve Küntay, A. (2013). Dil ve iletişim becerilerinin gelişiminde ebeveynlik etkileri. M. Sayıl, ve B. Yağmurlu (Ed.), Ana babalık: Kuram ve araştırma içinde (s. 295-327). İstanbul: Koç University Press.

Durham, R., Farkas, G., Hammer, C., Tomblin, J., \& Catts, H. (2007). Kindergarten oral language skill: A key variable in the intergenerational transmission of socioeconomic status. Research in Social Stratification and Mobility, 25, 294-305.

EDUCARE (2003). About. Erişim adresi: https://www.educareschools.org/

Ezell, H. K., \& Justice, L. M. (2005). Shared storybook reading: Building young children's language and emergent literacy skills. Baltimore, MD: Brookes Publishing.

Farkas, G., \& Beron, K. (2004). The detailed age trajectory of oral vocabulary knowledge: Differences by class and race. Social Science Research, 33(3), 464-497.

Farrant, B. M., \& Zubrick, S. R. (2013). Parent-child book reading across early childhood and child vocabulary in the early school years: Findings from the longitudinal study of Australian children. First Language, 33(3), 280-293.

Fernald, A., Marchman, V. A., \& Weisleder, A. (2013). SES differences in language processing skill and vocabulary are evident at 18 months. Developmental Science, 16(2), 234-248.

Finnegan, J., Telfer, C., Warren, H., Lawton, K., \& Nutbrown, E. (2015). Ready to read: Closing the gap in early language skills so that every child in Scotland can read well. Erişim adresi: https://resourcecentre.savethechildren.net/node/8462/pdf/read_on_get_on.pdf

Gilkerson, J., Richards, J. A., Warren, S. F., Montgomery, J. K., Greenwood, C. R., Kimbrough Oller, D., Hansen, J., \& Paul, T. D. (2017). Mapping the early language environment using all-day recordings and automated analysis. American Journal of Speech-Language Pathology, 26(2), 248-265.

Hart, B., \& Risley, T. R. (1995). Meaningful differences in the everyday experience of young American children. Baltimore, MD: Paul H Brookes Publishing Company

Hart, B., \& Risley, T. R. (1999). The social world of children: Learning to talk. Baltimore, MD: PH Brookes Publishing. 
Sosyoekonomik Risk Faktörlerinin Ebeveyn-Çocuk Etkileşimindeki Rolü: Paylaşımlı Kitap Okuma, Çocuğa Yöneltilen Dil, Sözcük Dağarcığı Farkı

Hart, B., \& Risley, T. R. (2003). The early catastrophe: The 30 million word gap by age 3. American Educator, 27(1), 4-9.

Hirsh-Pasek, K., Adamson, L. B., Bakeman, R., Owen, M. T., Golinkoff, R. M., Pace, A., Yust, P. K., \& Suma, K. (2015). The contribution of early communication quality to low-income children's language success. Psychological Science, 26(7), 1071-1083.

Hoff-Ginsberg, E. (1991). Mother-child conversation in different social classes and communicative settings. Child Development, 62(4), 782-796.

Hoff, E. (2003a). Causes and consequences of SES-related differences in parent-to-child speech. In M. H. Bornstein, R. H. Bradley (Ed). Socioeconomic status, parenting, and child development (s. 147-160). Mahwah, NJ, US: Lawrence Erlbaum Associates Publishers.

Hoff, E. (2003b). The specificity of environmental influence: socioeconomic status affects early vocabulary development via maternal speech. Child Development, 74(5), 1368-1378.

Hoff, E. (2006). How social contexts support and shape language development. Developmental Review, 26(1), 55-88.

Hoff, E. (2013). Interpreting the early language trajectories of children from low-SES and language minority homes: implications for closing achievement gaps. Developmental Psychology, 49(1), 4-14.

Hoff, E., Laursen, B., \& Tardif, T. (2002). Socioeconomic status and parenting. In. M. H. Bornstein (Ed.) Handbook of parenting: Biology and ecology of parenting (s. 231-252). Mahwah, NJ, US: Lawrence Erlbaum Associates Publishers.

Hoff, E., \& Naigles, L. (2002). How children use input to acquire a lexicon. Child Development, 73(2), 418-433.

Hurtado, N., Marchman, V. A., \& Fernald, A. (2008). Does input influence uptake? Links between maternal talk, processing speed and vocabulary size in Spanish-learning children. Developmental Science, 11(6), F31-F39.

Huttenlocher, J., Haight, W., Bryk, A., Seltzer, M., \& Lyons, T. (1991). Early vocabulary growth: Relation to language input and gender. Developmental Psychology, 27(2), 236-248.

Huttenlocher, J., Vasilyeva, M., Cymerman, E., \& Levine, S. (2002). Language input and child syntax. Cognitive psychology, 45(3), 337-374.

Huttenlocher, J., Vasilyeva, M., Waterfall, H. R., Vevea, J. L., \& Hedges, L. V. (2007). The varieties of speech to young children. Developmental Psychology, 43(5), 1062.

Işıkoğlu Erdoğan, N. (2016). Erken çocukluk döneminde çocuk-ebeveyn birlikte okuma etkinliklerinin incelenmesi. Kastamonu Eğitim Dergisi, 24(3), 1071-1086.

Justice, L. M., \& Pullen, P. C. (2003). Promising interventions for promoting emergent literacy skills: Three evidence-based approaches. Topics in Early Childhood Special Education, 23(3), 99-113.

Karacan, E. (2000). Language development of infants and children. Klinik Psikiyatri Dergisi, 3(4), 263268.

Kuo, A. A., Franke, T. M., Regalado, M., \& Halfon, N. (2004). Parent report of reading to young children. Pediatrics, 113(5), 1944-1951. Erişim adresi: https://pediatrics.aappublications.org/content/pediatrics/113/Supplement_5/1944.full.pdf

Kuo, A. A., Franke, T. M., Regalado, M., \& Halfon, N. (2004). Parent report of reading to young children. Pediatrics, 113(6), 1944-1951.

Lefebvre, P., Trudeau, N., \& Sutton, A. (2011). Enhancing vocabulary, print awareness and phonological awareness through shared storybook reading with low-income preschoolers. Journal of Early Childhood Literacy, 11(4), 453-479.

Levine, S. C., Suriyakham, L. W., Rowe, M. L., Huttenlocher, J., \& Gunderson, E. A. (2010). What counts in the development of young children's number knowledge? Developmental Psychology, 46(5), 1309-1319.

Logan, J. A., Justice, L. M., Yumus, M., \& Chaparro-Moreno, L. J. (2019). When children are not read to at home: The million word gap. Journal of Developmental \& Behavioral Pediatrics, 40(5), 383-386. 
Lonigan, C. J., Schatschneider, C., \& Westberg, L. (2008). Identification of children's skills and abilities linked to later outcomes in reading, writing, and spelling. Erişim adresi: https://lincs.ed.gov/publications/pdf/NELPReport09.pdf

Maviş, i. (2005). Çocukta dil edinim kuramları. S. S. Topbaş (Ed.), Dil ve kavram gelişimi içinde (s. 123-139). Ankara: Kök Yayıncılık.

Miller, P. J., \& Sperry, D. E. (2012). Déjà vu: The continuing misrecognition of low-income children's verbal abilities. In S. T. Fiske \& H. R. Markus (Eds.), Facing social class: How societal rank influences interaction (pp. 109-130). New York: Russell Sage Foundation.

Muslugüme, E. (2016). Dil gelişimini destekleyici ebeveyn eğitim programının sosyo ekonomik düzeyi düşük ailelerin çocuklarının dil gelişimine etkisi. (Yüksek Lisans Tezi). Pamukkale Üniversitesi Eğitim Bilimleri Enstitüsü, Denizli.

Öztürk Dağabakan, F. ve Dağabakan, D. (2007). Dil ve çocukta dil gelişim kuramları. Milli Eğitim Dergisi, 36(174), 155-161.

Raising Readers (2020). About us. Erişim adresi: https://www.raisingreaders.org/

Reese, E. (1995). Predicting children's literacy from mother-child conversations. Cognitive Development, 10(3), 381-405.

Rodríguez, B. L., Hines, R., \& Montiel, M. (2009). Mexican American mothers of low and middle socioeconomic status: Communication behaviors and interactive strategies during shared book reading. Language, Speech, and Hearing Services in Schools, 40(3), 271-282.

Rodriguez, E. T., \& Tamis-LeMonda, C. S. (2011). Trajectories of the home learning environment across the first 5 years: Associations with children's vocabulary and literacy skills at prekindergarten. Child Development, 82(4), 1058-1075.

Romeo, R. R., Leonard, J. A., Robinson, S. T., West, M. R., Mackey, A. P., Rowe, M. L., \& Gabrieli, J. (2018). Beyond the 30-Million-Word Gap: Children's conversational exposure is associated with language-related brain function. Psychological Science, 29(5), 700-710.

Rowe, M. L. (2008). Child-directed speech: Relation to socioeconomic status, knowledge of child development and child vocabulary skill. Journal of Child Language, 35(1), 185-205.

Santrock, J. W. (2014). Yaşam boyu gelişim (G. Yüksel, Çev.). Ankara: Nobel Akademik Yayıncılık.

Sarsour, K., Sheridan, M., Jutte, D., Nuru-Jeter, A., Hinshaw, S., \& Boyce, W. (2011). Family socioeconomic status and child executive functions: The roles of language, home environment, and single parenthood. Journal of the International Neuropsychological Society, $17(1), 120-132$.

Sénéchal, M., Thomas, E., \& Monker, J. A. (1995). Individual differences in 4-year-old children's acquisition of vocabulary during storybook reading. Journal of Educational Psychology, 87(2), 218-229.

Senemoğlu, N. (1989). Okulöncesi eğitimde dilin önemi. Milli Eğitim Vakfı Dergisi, 4(14), 21-22.

Shahaeian, A., Wang, C., Tucker-Drob, E., Geiger, V., Bus, A. G., \& Harrison, L. J. (2018). Early shared reading, socioeconomic status, and children's cognitive and school competencies: Six years of longitudinal evidence. Scientific Studies of Reading, 22(6), 485-502.

Snow, C. E., Pan, B. A., Imbens-Bailey, A., \& Herman, J. (1996). Learning how to say what one means: A longitudinal study of children's speech act use. Social Development, 5(1), 56-84.

Sperry, D. E., Sperry, L. L., \& Miller, P. J. (2019). Reexamining the verbal environments of children from different socioeconomic backgrounds. Child Development, 90(4), 1303-1318.

Suskind, D. (2018). Otuz milyon kelime: Çocuğunuzun beynini geliştirin (2. bs.). Ankara: Buzdağı Yayınevi.

Providence Talks (t.y.). About. Erişim adresi: http://www.providencetalks.org/

The Family Conservancy (t.y.). Start young: For success in wyandotte county. Erişim adresi: https://www.thefamilyconservancy.org/start-young-project/

Too Small To Fail (2014). Talking, reading and singing together. Talking is teaching. Erişim adresi https://talkingisteaching.org/

Turan, F. (2012). Normal ve özel gereksinimli çocuğu olan annelerin çocuklarının dil edinimine ilişkin 
Sosyoekonomik Risk Faktörlerinin Ebeveyn-Çocuk Etkileşimindeki Rolü: Paylaşımlı Kitap Okuma, Çocuğa Yöneltilen Dil, Sözcük Dağarcığı Farkı

görüşleri ile çocuklarıyla etkileşim biçimlerinin karşılaştııılması. Eğitim ve Bilim, 37(166), 290 302.

Turan, F. (2020). Erken okuryazarlık becerileri ve paylaşımlı kitap okuma. Ş. Ceylan (Ed.)., Çocuk edebiyatı içinde (s. 147-165). Ankara: Eğiten Kitap.

Turan, F. ve Akoğlu, G. (2014). Home literacy environment and phonological awareness skills in preschool children. Hacettepe University Journal of Education, 29(3), 153-166.

Turan F. ve Topcu, Z. G. (2016). İletişim ve dil gelişimi. N. Metin (Ed.). Doğum öncesinden ergenliğe çocuk gelişimi içinde (s. 123-163). Ankara: Pegem Akademi Yayıncılık.

Turan, F. ve Topcu, Z. G. (2018). Erken okuryazarlık üzerinde paylaşımlı kitap okumanın rolü: Okul ve ev ortamı açısından etkileri. H.Ü. Sağlık Bilimleri Fakültesi Dergisi, 5(1), 11-33.

Valdez-Menchaca, M. C., \& Whitehurst, G. J. (1992). Accelerating language development through picture book reading: A systematic extension to Mexican day care. Developmental Psychology, 28(6), 1106-1114.

Vroom (t.y.). Hello, Brain Builder. Erişim adresi: https://www.vroom.org/

What Works Clearinghouse (2015). Shared Book Reading. What Works Clearinghouse Intervention Report. Erişim adresi: https://ies.ed.gov/ncee/wwc/Docs/InterventionReports/wwc_sharedbook_041415.pdf

Wasik, B. A., \& Hindman, A. H. (2015). Talk alone won't close the 30-million word gap. Phi Delta Kappan, 96(6), 50-54.

Weisleder, A., \& Fernald, A. (2013). Talking to children matters: Early language experience strengthens processing and builds vocabulary. Psychological Science, 24(11), 2143-2152.

Weizman, Z. O., \& Snow, C. E. (2001). Lexical output as related to children's vocabulary acquisition: Effects of sophisticated exposure and support for meaning. Developmental Psychology, 37(2), 265-279.

Whitehurst, G. J., \& Lonigan, C. J. (1998). Child Development and Emergent Literacy. Child Development, 69(3), 848-872.

\section{Introduction}

\section{Extended Abstract}

Language development is a lifelong process that begins at birth. Child-directed speech is among the most critical environmental factors that shape children's language development. The relevant literature points out that parental child-directed speech shows substantial variances in quality and quantity depending on parental socioeconomic status. In this context, the present review attempted to address socioeconomic differences in parent-child interactions, such as child-directed speech and shared reading, especially the number of words heard in the early period. Ultimately, the research focused on how to struggle with likely risk factors due to income inequality in early childhood and discussed early childhood organizations at national and international levels to empower parents to optimize the development of their at-risk children.

\section{Socioeconomic Differences and Number of Heard Words: "The Thirty-Million-Word Difference"}

The idea that the number of words that children hear differs by socioeconomic level appeared as a result of the findings obtained by Hart and Risley $(1995,1999,2003)$, who observed 42 parents from various socioeconomic backgrounds and their children. Hart and Risley (1995) concluded that the number of words used by the parents and their way of speaking differed by their socioeconomic levels and that children in the low socioeconomic group seemed to hear cumulatively 30 million fewer words by age four than their peers in the high socioeconomic group. The longitudinal results of the study proved that there was an association between children's speech styles and parental child-directed speech in the early period and the number of words that the children heard (Hart \& Risley, 2003). Although the studies by Hart and Risley (1995, 1999, 2003) indicate that factors, such as the number of words used by parents in the early period and speech styles, may differ significantly by socioeconomic level, it should be noted that the literature hosts various methodological criticisms to these studies. Critics often questioned whether such robust 
conclusions could be drawn from a study where 42 families were observed for only one hour per month and only 29 children were longitudinally followed while attending primary school (Sperry et al., 2019; Suskind, 2018). At this point, a longitudinal study with 329 families to evaluate the natural language environment of infants and young children with age-appropriate development recorded the word counts of the adults around the child aged 2-48 months, the caregiver-child interaction, the frequency of the child's speech-sound and word production using LENA voice recorders. Consequently, the study found that while the frequency of speech-sound and word production of children increased with age, the number of adult words did not differ by age after early infancy. The findings also revealed that children from low socioeconomic levels produced fewer words, that adultchild interaction was more limited, and that they heard fewer words than adults when compared to their peers from higher socioeconomic levels. In addition, it was determined that there was only a four-million-word gap between the groups by age four (Gilkerson et al., 2017). Parallel to this finding, the literature previously showed that verbal stimuli are more limited in socioeconomically disadvantaged families than advantageous ones (Hoff, 2013; Huttenlocher et al., 2002; Huttenlocher et al., 2007). In a recent study examining the role of neural activations underlying the relationship between early language exposure and verbal skills, the researchers discovered that turn-based communication between child and adult significantly mediated the relationship between socioeconomic status and verbal ability and that the lower frontal lobe (Broca's Area) of the children with more turn-taking conversation showed more activation (Romeo et al., 2018). Therefore, the study highlights the importance of qualitative aspects of child-directed speech, Broca's Area activation, and both environmental and neural mechanisms underlying socioeconomic inequalities in early language skills.

\section{Socioeconomic Differences and Child-Directed Speech}

Even though the number of words heard in the first years is deemed critical for the vocabulary development of children, it may be the tip of the iceberg. Thus, the language presented to the child and the quality of parental speech have a critical role in fostering vocabulary development (Wasik \& Hindman, 2015). In the literature, there are also differences between the quantities of child-directed speech by socioeconomic status (Hart \& Risley, 1995; Hoff-Ginsberg, 1991; Hoff, 2003a, 2003b, 2006; Hoff \& Naigles, 2002). Parents with a high socioeconomic level use a wider variety of words when talking to their children, contributing to expanding children's vocabulary (Hoff, 2003a, 2003b; Hoff \& Naigles, 2002). However, socioeconomically disadvantaged and poorly educated parents tend to speak less and use fewer different words while interacting with their children (Hart and Risley, 1995; Hoff-Ginsberg, 1991). In this respect, it can be stated that growing up in an economically disadvantaged environment and being exposed to more limited speech input may lead to differences among children in the long term. From a developmental point of view, differences between infants' ability to process words and language become evident by 18 months by growing up in a low or high socioeconomic environment (Fernald et al., 2013). Differences in vocabulary development in the early period continue during primary school years, causing long-term adverse effects on children's reading achievement (Snow et al., 1996). The literature shows that parental language while reading to their children is more diverse in many respects compared to the language during their daily routines (eating, playing, dressing, etc.) and that stories contain various and rare words (De Temple \& Snow, 2003; Weizman \& Snow, 2001).

\section{Socioeconomic Differences and Shared Reading}

Considering that the number of words heard makes the difference in early language skills, there are some quantitative (reading frequency) and qualitative (parents' communication behaviors and reading strategies) differences in shared reading practices by socioeconomic level (Işıkoğlu Erdoğan, 2016; Kuo et al., 2004; Rodríguez et al., 2009; Shahaeian et al., 2018). In a study by Berkule et al. (2007), most of the socioeconomically disadvantaged at-risk mothers with newborn infants reported that they did not plan to practice shared reading and have children's books at home. Kuo et al. (2004) stated that $28 \%$ of mothers with low socioeconomic status practiced shared reading less 
than three days a week. In a study in our country, the researcher determined that parents with low education and socioeconomic status read less to their children (Işıkoğlu Erdoğan, 2016). Rodríguez et al. (2009) found the parents from a middle socioeconomic level tended to use interactive reading strategies, such as positive feedback and asking questions, more frequently than those from a low socioeconomic level. Limited use of interactive methods during shared reading practices may drive children to be passive listeners. Sénéchal et al. (1995) reported that the passive listeners during reading practices learned fewer words than children engaging in these practices actively. Based on this finding, it can be stated that interacting as an active participant in reading practices may function desirably in the development of early language skills.

\section{Results and Recommendations}

Overall, all relevant findings in the literature point out the contribution of parent-child communication and interaction to the optimum level of language and brain development. A language-rich environment forms the basis of verbal and non-verbal skills such as language and literacy, reasoning, mathematics, and social skills. The language environment at an early age has a critical place for children in the lifelong learning process. The previous research suggests that there are differences between the number of words heard, shared reading methods, and the quality and quantity of the words heard by socioeconomic level, which may adversely affect children. In this context, socioeconomically disadvantaged parents should be supported to enrich the early language environment of children at risk and reinforce their language and brain development. Given the impacts of early communication skills on language development, early literacy, school readiness, and academic skills in the following years, social initiatives and intervention programs developed to support at-risk parents are unfortunately limited in our country. However, these initiatives, aiming to strengthen parent-child interaction to support the language and brain development of socioeconomically disadvantaged children, may have an indispensable function in preventing vocabulary inequality in the early period. Thus, considering the long-term effects of social initiatives at the international level on children and parents, it is recommended to launch more protective and supportive social initiatives in our country, which may be structured in line with the needs of at-risk families. 